\title{
PCR-based VNTR core sequence analysis for inferring genetic diversity in the shrimp Litopenaeus vannamei
}

\author{
Patrícia Domingues de Freitas and Pedro Manoel Galetti Junior \\ Departamento de Genética e Evolução, Universidade Federal de São Carlos, São Carlos, SP, Brazil.
}

\begin{abstract}
The genetic variation in two farmed strains $\left(\mathrm{F}_{3}\right.$-Panama and $\mathrm{F}_{17}$-Venezuela) of the shrimp Litopenaeus vannamei was examined based on DNA multiloci analyses. Eighteen adults of each strain were analyzed by PCR using a set of VNTR core sequence primers. Genetic similarity, mean allele frequency, mean heterozygosity and the frequency of polymorphic loci were determined for both strains. A dendrogram of genetic similarity was produced by UPGMA clustering. The results for three primers (INS, M13, YN73) revealed different levels of genetic variation within the strains. The higher genetic similarity seen within strain $F_{17}$ was apparently related to inbreeding, although a bottleneck effect could not be discarded. The low level of genetic variability of this strain could account for the reduced adaptive advantage of these animals and their inability to adjust to breeding conditions in Brazil.
\end{abstract}

Key words: Litopenaeus vannamei, genetic diversity, shrimp, VNTR, PCR.

Received: April 6, 2002; October 4, 2002.

\section{Introduction}

Marine shrimp farming in Brazil has increased since the introduction of the species Litopenaeus vannamei from the Pacific Ocean. Currently, there are about 500 shrimp farms throughout Brazil, particularly in the northeastern region, with nearly $100 \%$ of all reared shrimp being $L$. vannamei (ABCC, 2002).

Despite several advantages, rearing exotic species can have undesirable consequences in a production system. The higher incidence of dwarf shrimps seen during harvesting may reflect genetic erosion within cultured stocks (Benzie et al., 1992, 1993). Bottleneck effects, often produced by the reduced number of broodstock used in each generation, can lead to decreased genetic variability and to the loss of rare alleles at certain loci (Perez and Romero, 1991). In addition, inbreeding progressively reduces the genetic variability and this can lead to a decrease in the mean size of the shrimps or to incomplete embryo development (Sunden and Davis, 1991). A close relationship between reduced genetic variability and a decline in spawning capacity has been reported for Marsupenaeus japonicus (Sbordoni et al., 1986).

In the past, enzymatic analyses were essential for initiating genetic studies on commercially-reared shrimps (Villaescusa et al., 1984; Alonso et al., 1987; Espinosa et al., 1989; Labacena et al., 1994; Díaz et al., 1995).

Send correspondence to: Pedro M.Galetti Júnior. Universidade Federal de São Carlos, Caixa Postal 676, 13565-905 São Carlos, SP, Brazil. E-mail: galettip@ power.ufscar.br.
However, more recently, various techniques in molecular biology have been used to characterize the genetic diversity and to establish DNA markers in several penaeid species (Garcia et al., 1996; Wolfus et al., 1997; Tassanakajon et al., 1997; Moore et al., 1999).

Restriction fragment length polymorphism (RFLP) and random amplified polymorphism DNA (RAPD) analyses have been used to assess the genetic diversity among different cultured stocks of L. vannamei shrimps (Garcia et al., 1996). In addition, microsatellite analyses have revealed specific genetic markers in L. vannamei and were able to detect different levels of genetic variation among wild populations (Wolfus et al., 1997). Genetic differences among cultured prawns L. vannamei (Garcia et al., 1996) and Penaeus monodon (Tassanakajon et al., 1997) have been reported based on the multiloci patterns obtained in RAPD analyses. Similarly, multiloci PCR-based VNTR (variable number of tandem repeats) analyses can be useful for assessing genetic diversity within and between wild species (Heath et al., 1993) and cultured strains (Bagshaw and Buckholt, 1995).

In the present work, PCR-based analyses using a set of VNTR core sequence primers were done to assess the genetic variability within and between two strains of $L$. vannamei, which have been farmed in Brazil for different numbers of generations.

\section{Material and Methods}

Samples were obtained from $18 \mathrm{~F}_{3}$ individuals of a strain owned by EMPARN (Empresa de Pesquisa 
Agropecuária do Rio Grande do Norte, Natal, RN), the $\mathrm{F}_{0}$ parents of which originally came from the Panama coast, and from $18 \mathrm{~F}_{17}$ individuals imported by AQUATEC Hatchery (Canguaretama, RN) from a Venezuelan shrimp farm. Genomic DNA was extracted from the hepatopancreas (frozen in liquid nitrogen) using phenol:chloroform: isoamyl alcohol $(25: 24: 1, \mathrm{v} / \mathrm{v})$ as described by Sambrook et al. (1989).

PCR was done using five universal VNTR core sequence primers (INS: 5' ACAGGGGTGTGGG 3', YNZ22: 5' CTCTGGGTGTCGTGC 3', YN73: 5' CCCG TGGGGCCGCCG 3', M13: 5' GAGGGTGGNGGNTCT 3' and PER1: 5' GACNGGNACNGG 3') selected from Heath et al. (1993). Each DNA amplification reaction used $200 \mathrm{ng}$ of prawn genomic DNA in a total reaction volume of $50 \mu \mathrm{L}$ containing 1x Cetus buffer (Gibco), $1.5 \mathrm{mM}$ $\mathrm{MgCl}_{2}, 0,2 \mathrm{mM}$ of each dNTP, $500 \mathrm{ng}$ of primer and 1 unit of Taq DNA polymerase (Gibco). The reactions were done in a Perkin Elmer Cetus DNA thermal cycler (model 2400) and involved denaturation for $3 \mathrm{~min}$ at $95{ }^{\circ} \mathrm{C}$ followed by 35 cycles of $95^{\circ} \mathrm{C}$ for $1 \mathrm{~min}, 55^{\circ} \mathrm{C}$ for $1 \mathrm{~min}$ and $72{ }^{\circ} \mathrm{C}$ for $1.5 \mathrm{~min}$, and a final extension at $72^{\circ} \mathrm{C}$ for $3 \mathrm{~min}$. The amplification products were analyzed by electrophoresis in $12 \%$ polyacrylamide gels $(5 \mathrm{~h}$ at $80 \mathrm{~V})$ and detected by silver nitrate staining (Sambrook et al., 1989). The fragment patterns of individuals were scored based on the absence or presence of bands, assuming that alleles from different loci did not co-migrate to the same position and that each fragment represented a Mendelian locus in which the visible dominant allele was in Hardy-Weinberg equilibrium with a recessive null allele or absent fragment (Lynch and Milligan, 1994).

The similarity coefficient $\left(\mathrm{S}_{\mathrm{j}}\right)$ (Jaccard, 1901) and a dendrogram of genetic similarity produced by UPGMA (the unweighted pair-group method with arithmetic averages) clustering method were obtained using the NTSYSPC program (Rohlf, 1988). The mean allele frequency $(\mathrm{q}=1-\sqrt{(1-S j)})($ Jeffreys and Morton, 1987) and the mean heterozygosity $\left(\mathrm{h}_{\mathrm{e}}=2(1-\mathrm{q}) /(2-\mathrm{q})\right)$ (Georges et al., 1988), both of which have been used successfully in RAPD analyses (Wasko and Galetti Junior, 2002) in which heterozygotic individuals could not be identified, and the frequency of polymorphic loci $\left(f=\mathrm{L}_{\mathrm{p}} / \mathrm{L}\right)$ (Ford, 1940), where $\mathrm{L}_{\mathrm{p}}=$ number of polymorphic loci and $\mathrm{L}=$ total number of loci, calculated for each primer, were determined.

\section{Results}

Electrophoretic analyses using the primers YN73, INS and M13 provided reliable, distinct multiloci band profiles for the two strains (Figure 1); no PCR products were obtained with PER1 and YNZ22. Twenty-seven loci 200-1000 bp long were analyzed. Jaccard's genetic similarity index showed higher values among the $\mathrm{F}_{17}$ individuals of the Venezuela lineage than for $\mathrm{F}_{3}$ of the Panama strain,

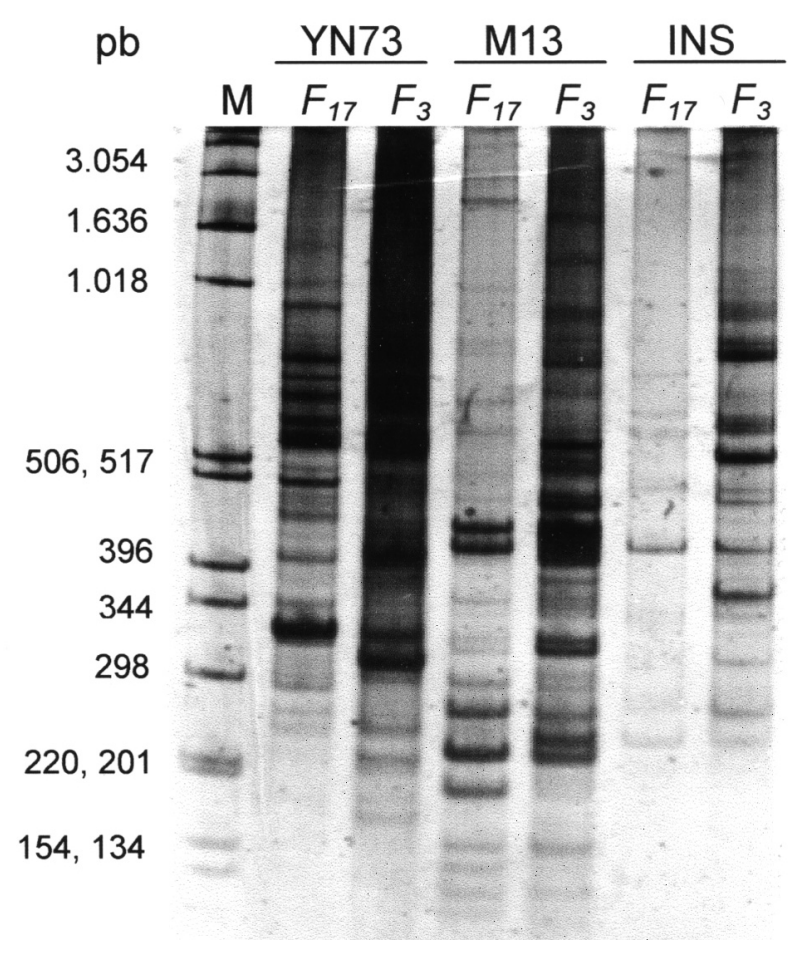

Figure 1 - Multiloci profiles obtained with the VNTR primers M13, YN73 and INS in two strains ( $\mathrm{F}_{3}$ Panama and $\mathrm{F}_{17}$ Venezuela) of $L$. vannamei.

even when the results for each primer were considered separately (Table I). All $\mathrm{F}_{17}$ individuals from the Venezuela strain were clustered at nearly $90 \%$ of genetic similarity, whereas the $\mathrm{F}_{3}$ individuals from the Panama strain had lower similarity values (Figure 2). Accordingly, the observed mean heterozygosity and the polymorphic loci frequencies were higher for $\mathrm{F}_{3}$ of the Panama strain, whereas the mean allele frequency was higher in $\mathrm{F}_{17}$ individuals of the Venezuela strain (Table II).

\section{Discussion}

L. vannamei is one of the main marine shrimp species used in commercial farming worldwide, especially in the American continent (Guerrelhas, 1997). There are extensive coastal areas dedicated to farming this species in Pan-

Table I - Jaccard's genetic similarity index (Sj) for both strains of $L$. vannamei $\left(\mathrm{F}_{3}\right.$ Panama and $\mathrm{F}_{17}$ Venezuela). The similarity index was obtained by considering each VNTR primer (M13, YN73, INS) separately, and then pooling the data.

\begin{tabular}{lcc}
\hline \multirow{2}{*}{ Jaccards Genetic Similarity } & \multicolumn{2}{c}{ Strains } \\
\cline { 2 - 3 } & $\mathrm{F}_{3}$ & $\mathrm{~F}_{17}$ \\
\hline $\mathrm{S}_{\mathrm{j}(\mathrm{M} 13)}$ & 0.679 & 0.888 \\
$\mathrm{~S}_{\mathrm{j}(\mathrm{YN} 73)}$ & 0.697 & 0.944 \\
$\mathrm{~S}_{\mathrm{j}(\mathrm{INS})}$ & 0.372 & 0.951 \\
$\mathrm{Sj}_{(\mathrm{M} 13, \mathrm{YN73}, \mathrm{INS})}$ & 0.56 & 0.91 \\
\hline
\end{tabular}




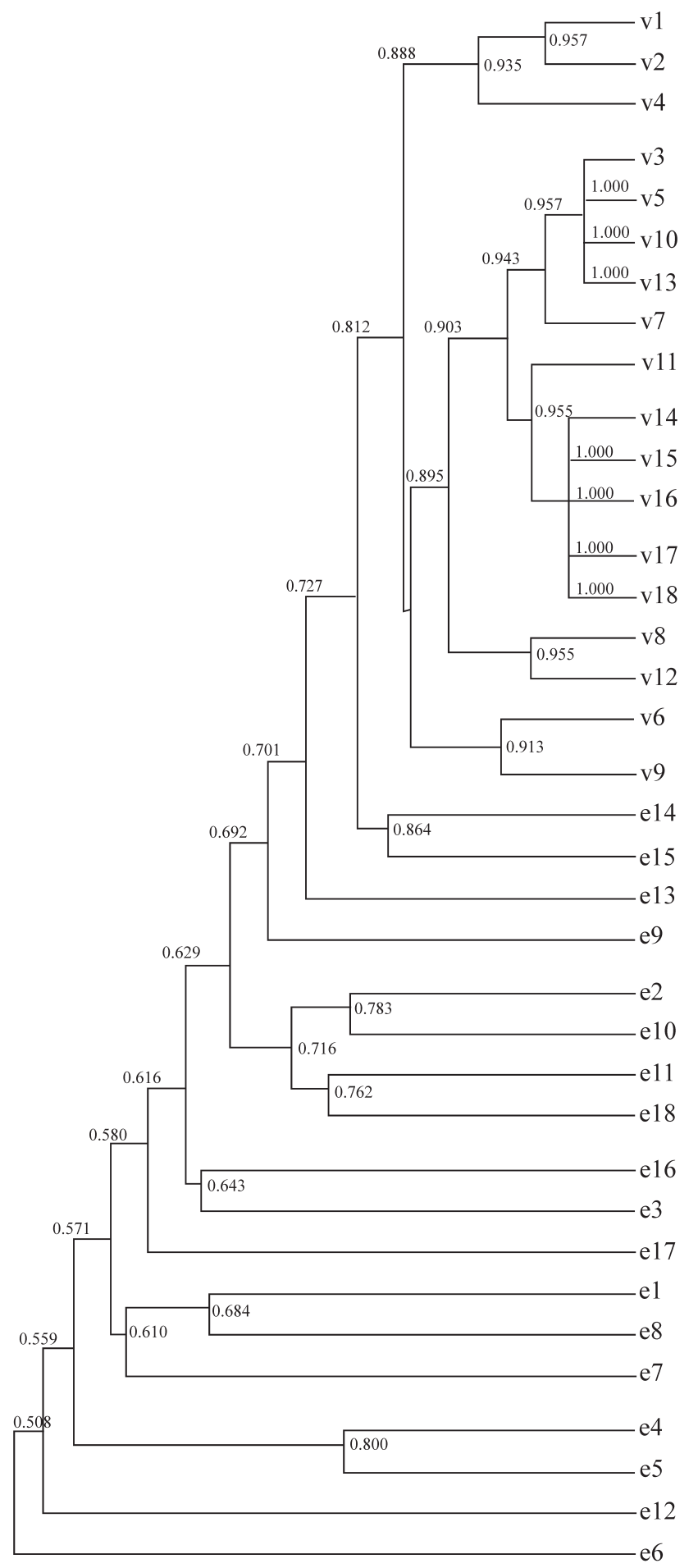

Figure 2 - Dendrogram of genetic similarity for individuals of $F_{3}$ Panama $\left(\mathrm{e}_{1}-\mathrm{e}_{18}\right)$ and $\mathrm{F}_{17}$ Venezuela $\left(\mathrm{v}_{1}-\mathrm{v}_{18}\right)$ based on the UPGMA method.

ama and Ecuador. Wild populations of $L$. vannamei do not occur on the Atlantic coast and farming of this species in Brazil was initially supported on the importation of specimens (larvae or adult stock). Currently, various farm-reared broodstock of this species are available from several Brazilian larvae-producing centers.
Table II - Frequency of polymorphic loci $(f)$, allele frequency $(q)$ and mean heterozygosity $\left(\mathrm{h}_{\mathrm{e}}\right)$ in $\mathrm{F}_{3}$ Panama and $\mathrm{F}_{17}$ Venezuela strains based on the VNTR primers M13, YN73, INS.

\begin{tabular}{lcc}
\hline Values & \multicolumn{2}{c}{ Strains } \\
\cline { 2 - 3 } & $\mathrm{F}_{3}$ & $\mathrm{~F}_{17}$ \\
\hline$f_{\text {(M13) }}$ & 0.89 & 0.44 \\
$f_{\text {(YN73) }}$ & 0.67 & 0.11 \\
$f_{\text {(IN) }}$ & 1.00 & 0.11 \\
$q$ & 0.34 & 0.70 \\
$\mathrm{~h}_{\mathrm{e}}$ & 0.795 & 0.461 \\
\hline
\end{tabular}

Species domestication can provide individuals more adapted to captive conditions, but also can lead to genetic losses (Wolfus et al., 1997). In agreement with this, the multiloci patterns obtained in the PCR-based VNTR analyses suggested that the $\mathrm{F}_{17}$ Venezuela strain consisted essentially of genetically very similar individuals when compared with Panama $\mathrm{F}_{3}$ individuals. The higher similarity scores among $F_{17}$ individuals appeared to reflect to their higher level of consanguinity, which probably resulted from inbreeding over generations. Genetic drift produced by mating a reduced number of individuals in each generation may also be present. As shown elsewhere, a bottleneck effect due to genetic drift could be the most important cause of the loss of genetic variation in inbred strains of $M$. japonicus (Sbordoni et al., 1986).

In contrast, individuals of the Panama $\left(\mathrm{F}_{3}\right)$ strain retained a wider genetic potential. The dendrogram of genetic similarity scores showed that individuals of this strain were genetically more distant from each other than were the individuals from the $F_{17}$ Venezuela strain. The higher genetic variation in the Panama strain could provide these shrimps with an advantage in adapting to different local environmental conditions.

The Venezuela $\mathrm{F}_{17}$ individuals were originally imported by a Brazilian breeder because of their high resistance to disease, good growth performance and reproductive profile. It was thought that these animals would do as well in Brazil as in their country of origin. However, this strain was adapted poorly to Brazilian conditions, and was highly susceptible to widespread viral diseases (Guerrelhas, personal communication). In agreement with this finding, SPF (specific pathogen free) strains of $L$. vannamei may vary appreciably in their susceptibility to disease and in their growth performance (Carr et al., 1994), thus limiting their use worldwide. Molecular analyses using microsatellite markers detected decreased mean heterozygosity $\left(\mathrm{h}_{\mathrm{e}}\right)$ in SPF shrimps (Wolfus et al., 1997). In the latter study, domesticated populations from Ecuador showed a marked reduction in genetic diversity in the $\mathrm{F}_{7}$ generation $\left(\mathrm{h}_{\mathrm{e}}=0.45\right)$ when compared to wild populations $\left(h_{e}=1.00\right)$. These authors believed that without adequate monitoring of the levels of genetic variation, the genetic diversity in $\mathrm{F}_{7}$ individuals could be com- 
pletely lost in the subsequent generations. The low levels of genetic variability seen in $\mathrm{F}_{17}$ individuals of the Venezuela strain could be responsible for the reduced adaptive advantage of these animals and their inability to adjust to breeding conditions in Brazil.

According to the Brazilian Association of Shrimp Farmers (Associação Brasileira de Criadores de Camarão), there are about 22 hatcheries in the country, mainly in the states of Piauí, Ceará, Rio Grande do Norte, Paraíba, Pernambuco, Bahia and Santa Catarina, and different inbred broodstock are currently used to produce either nauplii or post-larval individuals (ABCC, 2002). Assessing the genetic variability in such strains could help in deciding the appropriate time to introduce a new genetic pool (by mating genetically distant strains) and could contribute significantly to the development of genetic improvement programs. A knowledge of the genetic structure of the shrimp broodstock strain is an important step towards more predictable and sustainable shrimp farming.

\section{Acknowledgments}

The authors thank AQUATEC Htchery and Empresa de Pesquisa Agropecuária do Rio Grande do Norte (EMPARN) for helping to obtain the prawn samples and information on the history of two strains studied here. This work was supported by Associação Brasileira de Criadores de Camarão (ABCC), and Conselho Nacional de Desenvolvimento Científico e Tecnológico (CNPq).

\section{References}

ABCC (2002) O Agronegócio do Camarão Marinho Cultivado. Associação Brasileira de Criadores de Camarão, Recife, pp $1-20$.

Alonso BME, Joo L and Espinosa G (1987) Análisis electroforético y caracterización bioquímica de las esterasas de músculo en Penaeus notialis y Penaeus schmitti. Rev Invest Mar 9:1-10.

Bagshaw JC and Buckholt MA (1995) Application of DNA probe technology in shrimp aquaculture. In: Calderón $\mathrm{J}$ and Sorgeloos P (eds) II Congresso Ecuatoriano de Acuacultura, Ecuador, pp 29-33.

Benzie JAP, Ballment E and Frusher S (1993) Genetic structure of Penaeus monodon in Australia: concordant results from mtDNA and allozymes. Aquaculture 111:89-93.

Benzie JAH, Frusher S and Ballment E (1992) Geographical variation in allozyme frequencies of Penaeus monodon (Crustacea: Decapoda) populations in Australia. Aust J Mar Fresh Res 43:715-725.

Carr WH, Sweeney J and Swingle J (1994) The Oceanic Institute's SPF shrimp breeding program status USMSFP (US Marine Shrimp Farming Program). 10 ${ }^{\text {th }}$ Anniversary Review. GCRL. Special Publication 1:47-54.

Díaz R, Márquez ME, Espinosa G and Berovides V (1995) Estudio morfometrico y electroforetico de tres especies de camarones peneidos comerciales en cultivo. Rev Invest Mar 16:1-3.
Espinosa G, Berovides V and Díaz R (1989) Genética bioquímica y morfometria del camarón blanco P. schmitti de Cuba. Rev Invest Mar 10:157-162.

Ford EB (1940). Polymorphism and taxonomy. In: Huxley J (ed) The New Systematics, Clarendon Press, Oxford, pp 493-513.

Garcia DK, Dhar AK and Alcivar-Warren AA (1996) Molecular analysis of RAPD marker (B20) reveals two microsatellites and differential mRNA expression in Penaeus vannamei. Mol Mar Biol Biotechnol 5:71-83.

Georges M, Lequarre AS, Castelli M, Hanset R and Vassart G (1988) DNA fingerprinting in domestic animals using four different minisatellite probes. Cytogenet Cell Genet 47:127-131.

Guerrelhas ACB (1997) Seed production of Penaeus vannamei in Brazil. IV Simposio Centroamericano de Acuacultura, Teguncigalpa, Honduras, pp 152-153.

Heath DD, Iwama K and Delvin RH (1993) PCR primed with VNTR core sequences yields species specific patterns and hypervariable probes. Nucleic Acids Res 21:5782-5785.

Jaccard P (1901) Étude comparative de la distribution florale dans une portion des Alpes et des Jura. Bull Soc Vaudoise Sc Nat 37:547-579.

Jeffreys AJ and Morton DB (1987) DNA fingerprinting of dogs and cats. Anim Genet 18:1.

Labacena ME, Torres M and Espinosa G (1994) Variabilidad y distancia genetica en especies de Penaeus. Rev Invest Mar 15:80-87.

Lynch M and Milligan BG (1994) Analysis of population genetic structure with RAPD markers. Mol Ecol 3:91-99.

Moore SS, Whan V, Davis GP, Byrne K, Hetzel DJS and Preston N (1999) The development and application of genetic markers for the Kuruma prawn Penaeus japonicus. Aquaculture 173:19-32.

Perez JE and Romero OZ (1991) Genetic improvement in crustaceans. Est Ocean 10:131-137.

Rohlf FLJ (1988) Numerical Taxonomy and Multivariate Analysis System, NTSYS-PC. Exeter Publishing, New York.

Sambrook J, Fritsch EF and Maniatis T (1989) Molecular Cloning: a Laboratory Manual. 2nd ed. Cold Spring Harbor Laboratory Press, Cold Spring Harbor, New York.

Sbordoni V, De Matthaeis E, Cobolli-Sbordoni M, La Rosa G and Mattoccia M (1986) Bottleneck effects and depression of genetic variability in hatchery stocks of Penaeus japonicus (Crustacea, Decapoda). Aquaculture 57:239-251.

Sunden SLF and Davis SK (1991) Evaluation of genetic variation in a domestic population of Penaeus vannamei (Boone): a comparison with three natural populations. Aquaculture 97:131-142.

Tassanakajon A, Siriporn P and Rimphanitchayakit V (1997) Random amplified polymorphic DNA (RAPD) markers for determination of genetic variation in wild populations of the black tiger (Penaeus monodon) in Thailand. Mol Mar Biol Biotechnol 6:110-115.

Villaescusa A, Camacho A and Rivalta V (1984) Polimorfismo de la fosfoglucosa isomerasa y de la fosfoglucomutasa en el camarón rosado (Penaeus notialis). Cienc Biol 12:23-29.

Wasko AP and Galetti Junior PM (2002) RAPD analysis in the neotropical fish Brycon lundii: genetic diversity and its implication for the conservation of the species. Hydrobiologia 473:131-137.

Wolfus GM, Garcia DK and Alcivar-Warren AA (1997) Application of the microsatellite technique for analyzing genetic diversity in shrimp breeding programs. Aquaculture 152:35-47. 